\title{
Numerical modeling of earthquake impact on engineering structures on Arctic shelf
}

\section{I.B. Petrov, V.I. Golubev, K.A. Beklemisheva, A.V. Vasukov **}

Moscow Institute of Physics and Technology, Dolgoprudny, Russian Federation

The problem of numerical modeling of the process of initiation of seismic activity on Arctic shelf and its impact on engineering structures is considered. To describe the dynamic behavior of a geological array, the determining systems of equations of the theory of elasticity and acoustics are used with explicit identification of all geological layers. A distinctive feature of the developed approach is the full wave calculation of the propagation of seismic waves from the source of the earthquake to the day surface. Grid-characteristic method is used for numerical calculation on hexahedral and tetrahedral computational grids.

Keywords: mathematical modeling, grid-characteristic method, earthquake, seismic stability, parallel algorithms

Introduction. Currently, oil and natural gas are the main sources of energy. A significant part of their deposits is located on the shelf, which causes difficulties with their exploration and development, including building complex engineering structures on the shelf. An important issue is also the transportation of raw materials from the wellhead to the site of its accumulation, for which many kilometers of pipelines are laid along the seabed. One of the significant threats is deformation and destruction of the structures in question due to seismic activity (earthquake) in the region.

Today, an innovative technological solution is the usage of composite materials for complex engineering structures. At the same time, a lot of scientific collectives around the world are engaged in studying the process of destruction of composite materials. The main results of a series of international projects WWFE (World Wide Failure Exercise), entirely devoted to the development and comparison of the criteria for volumetric destruction of polymer composite materials (PCM) with the reinforcement of long fibers, are given, for example, in $[1,2]$. To date, many different destruction criteria have been developed, describing in-depth experiments with varying degrees of reliability. These include the criteria of Hashin, Pak, Tsai-Hill, Tsaya-Vu and Drucker-Prager.

In this paper, we consider the problem of propagation of seismic waves from the source of an earthquake in the shelf region and the destruction of an engineering structure under their influence (composite pipeline is taken as an example structure). The mathematical formulation of the problem includes a system of equations of the theory of acoustics and linear elasticity, taking into account the anisotropy of the material [3]. A calculation algorithm is based on a sequential solution of two

\footnotetext{
**E-mail: petrov@mipt.ru,w.golubev@mail.ru, amisto@yandex.ru,vasyukov@gmail.com The study was supported by RFBR, research project 16-07-00233
} 
problems (propagation of the seismic wave from the source of the earthquake to the bottom and its dynamic effect on the structure).

For the description of seismic processes on the shelf, a geological multilayer model is initially constructed whose behavior is described by a system of linear elasticity (geological rocks) and an acoustics system (water), and a solution of these systems is made jointly at the sea-sea bottom contact. For a numerical solution, a grid-characteristic method is used on hexahedral grid designs [4, 5].

To describe the destruction processes in a composite pipe, a grid-characteristic method is used on tetrahedral grids for a linearly elastic anisotropic material [6, 7]. Criteria for destruction of composites based on a certain set of material parameters available for direct measurement are used: the criteria of Hashin, Pak, Tsai-Hill, Tsaya-Vu and Druger-Prager. A detailed description of these criteria and their comparison with each other and experiment is given in [8]. These criteria are used in many commercial settlement packages.

The calculation of the propagation of seismic waves from the source of the earthquake in a three-dimensional model of a multilayer medium describing the sea shelf was carried out. The following layers were included in the calculation: the water layer, bottom sediment layer, two geological layers and the crystalline basement. All the characteristics of the materials were chosen on the basis of [9]. The entire cubic grid consisted of 192 million nodes in 5 meters increments and covered an area of $4000 \times 4000 \times 1500 \mathrm{~m}$. The earthquake source was located at a depth of $1150 \mathrm{~m}$ and was a plane of discontinuity with a velocity inversion of $50 \times 50 \times 150 \mathrm{~m}$ [10]. The parameters of the earthquake source model were reconstructed on the basis of the analysis of the maximum displacements of the seabed in accordance with the Richter scale [11]. During the simulation, the values of the total stress tensor at the level of the seabed were taken, which were subsequently used to calculate the process of dynamic loading of the composite pipe.
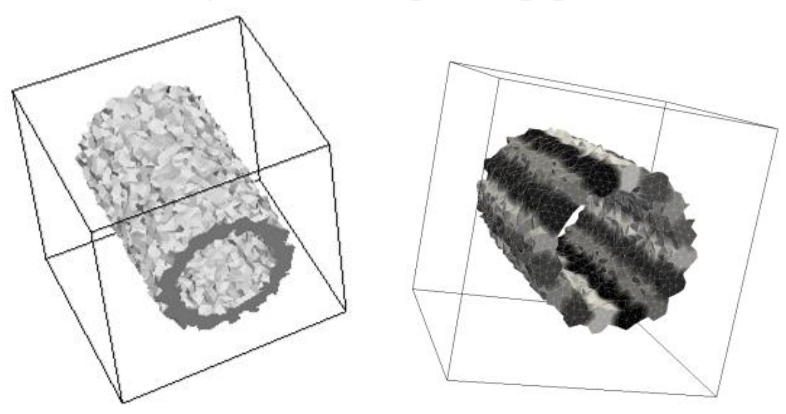

Fig. 1. General view of the calculation area: on the left - a general view, on the right - a general view showing materials with different directions

To model the destruction of a composite pipe, the volume of soil around a short straight pipe segment was taken. The radius of the pipe is $25 \mathrm{~cm}$, the thickness is $6 \mathrm{~cm}$. The face of the cube is 1 $\mathrm{m}$. The pipe axis is directed along the $\mathrm{X}$ axis, the vertical axis is the $\mathrm{Y}$ axis. The general form of the calculated region is shown in Fig. 1. To model the curved anisotropic pipe material, it was divided into 16 segments, the material of each of which (carbon plastic, the properties of the materials given in [12]) are rotated relative to the neighboring ones. Two cases were considered: the direction of the fibers along the $\mathrm{X}$ axis and perpendicular to it. 
A series of calculations was performed with increasing intensity of the earthquake. With an earthquake strength of 1 point, no damage was observed, with a strength of more than 3 points, the entire volume of the composite material was destroyed.

A typical form of the wave pattern in the propagation of seismic waves from the source of the earthquake is shown in Fig. 2.

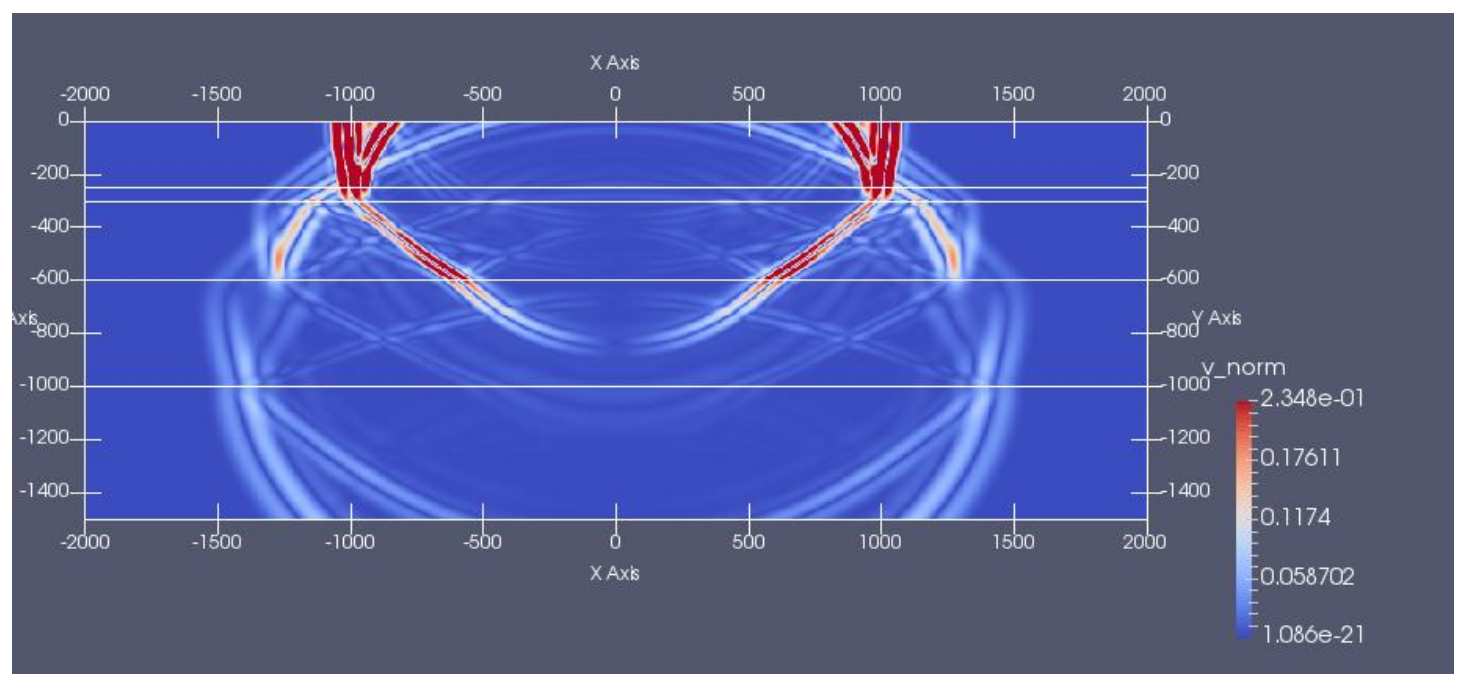

Fig. 2. Characteristic view of the wave pattern in the propagation of seismic waves from an earthquake source

Criterion Hashin allows you to analyze the mechanisms by which the destruction occurred. With an earthquake strength of 2 points, small stratifications occur at the bottom of the pipe. With an earthquake strength of 2.5 points, stratifications occur throughout the pipe wall, part of the composite matrix is cracked. With the strength of an earthquake of 3 points, stratification and cracking of the matrix occur throughout the volume, part of the fibers in the lower part of the tube breaks. A series of calculations was performed with a changed laying of the fibers - perpendicular to the axis of the tube. At an earthquake strength of 2 points, significant stratifications occur in the lower and upper parts of the pipe. With an earthquake strength of 2.5 points, stratifications occur throughout the pipe wall, part of the composite matrix in the lower part of the pipe is cracked. With the strength of an earthquake of 3 points, stratification and cracking of the matrix occur throughout the volume, no breaking of the fibers occurs.

Fracture regions were also calculated for various earthquake strengths and various mechanisms in the Hashin criterion, when the fibers directed perpendicular to the axis of the tube. With an earthquake strength of 2 points, significant stratifications occur in the lower and upper parts of the pipe. With a force of 2.5 points, stratifications occur along the entire tube wall, part of the composite matrix in the lower part of the pipe is cracked. With a strength of 3 points, stratification and cracking of the matrix occur throughout the volume, no breaking of the fibers occurs.

With a change in the direction of laying of fibers, the pattern of destruction varies markedly. When laying the fibers parallel to the axis of the tube, the bundle is smaller in the case of a weak earthquake, but with a strong earthquake, the fibers are destroyed, which is not present when the fibers are laid perpendicular to the axis. 
Hashin's criterion allows for a detailed analysis of the destruction of the material-adjust the response from the fracture region in accordance with the fracture mechanism and analyze the residual strength of the part. When calculating real constructions, the application of this criterion is complicated by the fact that it can be used only for monolayers, but not for an averaged anisotropic material consisting of several monolayers with different packing. Therefore, the pipe will have to be modeled to within a monolayer, which will significantly increase the computational complexity of the problem.

Conclusion. The paper describes a new approach that makes it possible to estimate the degree of destructive effect of an earthquake with a given magnitude on a shelf structures by direct numerical simulation of the process of propagation of seismic waves from the source to the day surface, taking into account the detailed geological structure of the underlying massif. It is based on the numerical solution of acoustic equations and elasticity equations by a grid-characteristic numerical method on hexahedral and tetrahedral computational grids.

A calculation algorithm is based on a sequential solution of two problems - propagation of the seismic wave from the source of the earthquake to the bottom and its dynamic effect on the structure. Calculations of seismic load on an underwater pipeline were performed for various earthquake strengths using the proposed algorithm and seismic profiling data from Arctic shelf.

\section{References}

1. Hinton M.J., Kaddour A.S., Soden P.D. Failure criteria in fiber reinforced polymer composites: the world-wide failure exercise. - Amersterdam; London: Elsevier, $2004-1268$ p.

2. Hinton M.J., Kaddour A.S. Maturity of 3D failure criteria for fiber-reinforced composites: Comparison between theories and experiments: Part B of WWFE-II // Journal of Composite Materials. - 2013. - № 7. - P. 925-966.

3. Sedov L.I. Continuum mechanics. V.1. - Moscow: Nauka, 1970. - 492 p.

4. Golubev V.I., Petrov I.B., Khokhlov N.I. Software development to assess seismic resistance to oil and gas complex facilities, the Society of Petroleum Engineers - SPE Arctic and Extreme Environments Conference and Exhibition, AEE. - 2013. - V. 3. - pp. 2068-2082.

5. Golubev V.I., Petrov I.B., Khokhlov N.I., Shul'ts K.I. Numerical computation of wave propagation in fractured media by applying the grid-characteristic method on hexahedral meshes // Computational Mathematics and Mathematical Physics. - 2015. - V. 55. - No. 3. - pp. 509-518.

6. Petrov I. B., Favorskaya A. V., Vasyukov A. V., Ermakov A. S., Beklemysheva K. A., Kazakov A. O., Novikov A. V. .. Numerical simulation of wave propagation in anisotropic media // Doklady mathematics - 2015 - V.90. - No. 3. - pp. 778-780.

7. Beklemysheva K.A., Danilov A.A., Petrov I.B., Salamatova V.Yu., Vassilevski Yu.V., Vasyukov A.V. Virtual blunt of human thorax: Age-dependent response of the vascular system // Russian Journal of Numerical Analysis and Mathematical Modeling. - 2015. - V.30. - № 5. - pp. 259-268.

8. Beklemysheva KA, Vasyukov AV, Ermakov AS, Petrov IB Numerical simulation with grid-characteristic method of destruction of composite materials // Mathematical modeling. - 2016. - V.28. -. №2. - pp. 97-110.

9. Zaslavsky Yu.M., Kerzhakov B.V., Kulinich V.V. Vertical seismic profiling on the sea shelf. // Acoustic journal. 2008. - V.54. - No. 3. - pp. 483-490. 
10. Golubev V.I., Kvasov I.E., Petrov I.B. Influence of natural disasters on ground facilities. Mathematical Models and Computer Simulations. - 2012. - V.4. - №2. - pp. 129-134.

11. Richter C.F. An instrumental earthquake magnitude scale // Bulletin of the Seismological Society of America. - 1935. - V.25 - No.1. - pp.1-32.

12. Petrov I. B., Vasyukov A. V., Beklemysheva K. A., Ermakov A. S., Dziuba A. S., Golovan V. I. .. Numerical modeling of low energy stratification at the strestrine panel. // Mathematical Modeling. - 2014. - V.26. - №9. - pp. 96-110.

\section{Authors:}

Petrov Igor Borisovich, Corresponding Member of the Russian Academy of Sciences, Professor, Doctor of Science in Physics and Maths, Moscow Institute of Physics and Technology (State University), (9 Institutsky per., Dolgoprudny Moscow Region, Russian Federation)

Golubev Vasily Ivanovich, Candidate of Science in Physics and Maths, Senior Researcher in the Laboratory of Applied Computational Geophysics, Moscow Institute of Physics and Technology, Associate Professor of the Department of Informatics and Computational Mathematics, Moscow Institute of Physics and Technology (State University), (9 Institutsky per., Dolgoprudny Moscow Region, Russian Federation)

Beklemysheva Katerina Alekseevna, Candidate of Science in Physics and Maths, Moscow Institute of Physics and Technology (State University), (9 Institutsky per., Dolgoprudny Moscow Region, Russian Federation)

Vasyukov Alexey Viktorovich, Candidate of Science in Physics and Maths, Moscow Institute of Physics and Technology (State University), (9 Institutsky per., Dolgoprudny Moscow Region, Russian Federation) 
УДК 004.942

\section{Численное моделирование сейсмической нагрузки на инженерные конструкции на арктическом шельфе}

\section{И.Б. Петров, В.И. Голубев, К.А. Беклемышева, А.В. Васюков ${ }^{* *}$}

Московский физико-технический институт, г. Долгопрудный, Россия

Рассматривается задача численного моделирования процесса инициации сейсмической активности на шельфе и её разрушающего воздействия на инженерные конструкции. Для описания динамического поведения геологического массива используются определяющие системы уравнений теории упругости и акустики с явным выделением всех геологических слоёв. Отличительной особенностью разработанного подхода является полноволновой расчёт распространения сейсмических волн от очага землетрясения к дневной поверхности. Для численного расчёта используется сеточно-характеристический метод на гексаэдральных и тетраэдральных расчётных сетках.

Ключевые слова: математическое моделирование, сеточно-характеристический метод, землетрясение, сейсмостойкость, параллельные алгоритмы

\section{Авторы:}

Петров Игорь Борисович, член-корреспондент РАН, профессор, доктор физикоматематических наук, Московский физико-технический институт (государственный университет), г. Долгопрудный Московской обл. (Россия, 141700, г. Долгопрудный Московской обл., Институтский пер., 9)

Голубев Василий Иванович, кандидат физико-математических наук, старший научный сотрудник в лаборатории прикладной вычислительной геофизики МФТИ, доцент кафедры информатики и вычислительной математики, Московский физико-технический институт (государственный университет), г. Долгопрудный Московской обл. (Россия, 141700, г. Долгопрудный Московской обл., Институтский пер., 9)

Беклемышева Катерина Алексеевна, кандидат физико-математических наук, Московский физико-технический институт (государственный университет), г. Долгопрудный Московской обл. (Россия, 141700, г. Долгопрудный Московской обл., Институтский пер., 9)

Васюков Алексей Викторович, кандидат физико-математических наук, Московский физикотехнический институт (государственный университет), г. Долгопрудный Московской обл. (Россия, 141700, г. Долгопрудный Московской обл., Институтский пер., 9)

\footnotetext{
**E-mail: petrov@mipt.ru,w.golubev@mail.ru, amisto@yandex.ru, vasyukov@gmail.com. Работа выполнена при поддержке РФФИ, проект 16-07-00233
} 